\title{
Physicochemical and Sensorial Analysis of Papaya Varieties in Ethiopia
}

\author{
Mulate Zerihun, Masresha Minuye \\ Melkassa Agriculture Research Center (Food Science and Nutrition), EIAR, Addis Ababa, Ethiopia \\ Email address: \\ mulatezerihun@yahoo.com (M. Zerihun), masreshaminuye@gmail.com (M. Minuye)

\section{To cite this article:} \\ Mulate Zerihun, Masresha Minuye. Physicochemical and Sensorial Analysis of Papaya Varieties in Ethiopia. International Journal of Food \\ Engineering and Technology. Vol. 4, No. 2, 2020, pp. 46-51. doi: 10.11648/j.ijfet.20200402.16
}

Received: November 1, 2019; Accepted: December 9, 2019; Published: September 23, 2020

\begin{abstract}
A study was carried out on three papaya varieties namely, KK-103, MK-121 and CMF-078 for their physicochemical, nutritional composition and sensory evaluation grown at Ethiopia. The results showed that maximum fruit weight was observed in MK-121 and lowest in CMF-078. It was also found that the TSS, citric acid, total carotenoid and vitamin C were 10.287-12.620 (brix), 1.455- $1.978(\mathrm{~g} / \mathrm{l}), 13.670-18.912(\mu \mathrm{g} / \mathrm{g})$ and 30.854-36.507 (mg/100g) respectively. Proximate analysis of the pulp showed that it contained crude protein $(0.200-0.907 \%)$, energy $(32.744-44.280 \mathrm{kcal} / \mathrm{g})$, crude fat $(0.215$ $0.293 \%)$ and fibre $(0.732-0.995 \%)$. All these results indicate that significantly difference between the papaya varieties. This difference may be come from genetically difference between the varieties. The results showed that papaya fruits had high moisture content $(>85.5 \%)$, low acidity $\left(>5.3 \mathrm{P}^{\mathrm{H}}\right)$, low crude fat and crude fibre moderate ascorbic acid contents. The sensory evaluation statistical results were showed in case of color, flavor, sourness and sweetness MK-121 Varity was showed significance difference and a higher value than the other two of varieties of papaya whereas except sweetness. The color, flavor and sourness of the two varieties (CMF-078 and kk-103) were showed the same in statistics value. Accordingly, the panelist result in overall acceptability of the sensory CMF-078 variety was showed high acceptability than the others two varieties. Additionally, the statistical result showed significantly different at $\mathrm{P}<0.05$.
\end{abstract}

Keywords: Papaya, Physiochemical Composition and Proximate Analysis, Sensory Evaluation

\section{Introduction}

Papaya (Carica papaya L.) is one of the important and versatile fruits of the family Caricaceae and grown worldwide in the tropics and subtropics including India, Bangladesh, Malaysia, Australia, Hawaii, Philippines, Sri Lanka, South Africa and other countries in tropical America [1]. Papaya has been ranked one of the tops for nutritional scores among 38 common fruits [2]. It is available all around the year; therefore, ripe papaya is consumed as fruit and green papaya as vegetable. Carica papaya L. is part of Caricaceae family, and a variety of Caricaceae types have medicinal properties and have been used against diseases for many years $[3,4]$. Practically every part of the fruit is used in variety medical purposes $[5,6]$. It has been argued by scientists that all parts of papaya, including seeds, roots, rinds, and fruits have positive effects on general health preventing diseases [6, 7].

Fruit quality is one of the most important themes of fruit industry, especially when concerning juice and pulp ones. Since they have a direct impact on the use of synthetic products such as acidifiers, colorants and sugars, for instance, i.e., fruits with adequate physical and chemical properties have the use of synthetic composts reduced on their processed products. The physical and chemical parameters of fruits are important indicators of their maturation and internal and external quality, decisive factors for accomplishment of market demands that have encouraged many researches under different conditions overseas $[8,9]$.

Papaya fruit quality is affected by the ripening process [10]. Quality is defined as the absence of defects or degree of excellence and it includes appearance, color, shape, injuries, flavor, taste, aroma, nutritional value and being safe for the consumer $[10,11]$. Due to a higher market exigency as for high quality products, the juice and pulp industries have been looking for fruits with better internal and external features, including fruit length and width, fruit weight, pulp, seed, peel percentages per fruit, number of 
seeds per fruit, seed size, peel diameter, soluble solids ( ${ }^{\circ}$ Brix); titratable acidity (\%), vitamin C content (mg/100g of fresh fruit), pulp $\mathrm{pH}$ and soluble solids/titratable acidity ratio $[9,12,13]$.

Papaya is the main source of many vitamins, such as vitamin $\mathrm{C}$ containing also vitamin $\mathrm{E}$, pectin, and carotenoids [14]. Based on the multipurpose and available all around the year of papaya varieties the quality parameters of papaya which is grown in Ethiopia is not studied yet. Three released and improved papaya varieties investigated in the present study which was grown at Ethiopian. The need exists to investigate the quality of papaya fruit varieties is good for consuming or for processing; such variations with regard to different papaya cultivars [15]. Until now, a full characterization and comparison of the quality attributes of the papaya varieties have not yet been investigated. Physicochemical characteristics are important qualitative indexes of any fruit for fresh consumption. Hence, the main objective of the present study was to conduct a detailed analysis and to assess the variations in physicochemical characteristics and sensory evaluation of papaya fruit varieties cultivated in Ethiopia. The main theme behind carrying out this study was to convey information to the local growers and industrialists about the physicochemical and sensorial attributes of the above varieties thus helping them in selection of the appropriate variety for cultivation, consumption and industrial processing at regional level.

\section{Materials and Methods}

\subsection{Sample Collection and Preparation}

This study was conducted in food science and postharvest technology research laboratory of Melkassa agricultural research center. The samples were collected from different tree of papaya; for one variety at least from eight (8)-papaya trees were collected randomly from Melkassa agricultural research center in horticultural research stations. The papaya samples were free from mechanical damage, insect infestation, disease and physiological deterioration. A total of three papaya varieties (kk-103, MK-121, CMF-078) were collected at similar stage of maturity. The collected samples were stored at 12 degrees Celsius for further analysis.

\subsection{Sample Preparation}

The freshly collected samples of papaya varieties were washed with deionizer water to remove surface dust particles, pathogens from the surface, and the water quickly with a blotting paper and with the aid of a clean sharp knife; the peels, pulp and seed (kernel) of the papaya fruits were removed and homogenized. The fleshes papaya fruits were dried with lyophilizer for further analysis and some of the fresh fleshes fruits were made juice to perform some physicochemical parameters, nutritional composition and sensory analysis. All the experimental analyses were carried out in triplicate analysis.

\subsection{Physical and Chemical Properties Analysis}

Color of skin and flesh: The color of skin and flesh of papaya varieties were determined through the standard method using color chart [16].

Fruit weight: The fruit weight of papaya varieties was determined through the standard method using sensitive balance [17].

Fruit width, length and diameter: The fruit widths, length, diameter of papaya varieties were determined through the standard method using digital caliper [18].

$\mathrm{P}^{\mathrm{H}}$ : The $\mathrm{P}^{\mathrm{H}}$ of the papaya fruit was measured by taking a sufficient quantity of papaya juice sample in $50 \mathrm{~mL}$ clean beaker and then the electrode of the $\mathrm{P}^{\mathrm{H}}$ was immersed in to the juice through $\mathrm{P}^{\mathrm{H}}$ meter [19].

Total Soluble Solid content (TSS): The TSS of papaya varieties was determined using an Atago hand refractometer [20]. A drop of homogenized papaya pulp was placed at the prism of a hand refractometer, which had been calibrated, the lid closed and TSS read directly from the digital scale at $20^{\circ} \mathrm{C} \pm 1$ and results expressed in Brix.

TA (Titerable acidity): The TA value was calculated through the standard method of AOAC (2000) [21]. Zero point zero one molar $(0.01 \mathrm{M}) \mathrm{NaOH}$ was titrate against $10 \mathrm{ml}$ of the filtrate using phenolphthalein indicator. The end of the titration was indicated through a change in color of the sample to pink. The amount of acid in milligram per hundred grammars $(\mathrm{mg} / 100 \mathrm{~g})$ was calculated as stated below.

$$
\text { Titratable acidity }=\frac{0.01 \times 0.0064 \times \mathrm{T} \times 10 \times 10}{\mathrm{Ft} \times \mathrm{S}}
$$

Where $0.01 \mathrm{M}=$ morality of $\mathrm{NaOH}$ used

$0.0064=$ conversion factor for citric acid, since it is present in papaya.

$\mathrm{T}=$ titer value, $\mathrm{Ft}=$ quantity of filtrate used, $\mathrm{S}=$ quantity of sample weighed

$10=$ dilution factor, and $1000=$ conversion to $\mathrm{mg} / 100 \mathrm{~g}$

Ash (Total Mineral): The ash content was determined followed the standard method described in AOAC (2000) [22]. $2 \mathrm{~g}$ of dry ground sample was weighted into a clean crucible of predetermined weight. The weight of the sample and crucible was record respectively. The sample was burnt in the muffle furnace at $550^{\circ} \mathrm{C}$ until the color changed to grey/white hours. The crucible was removed with tong and allowed to cool in desiccators for 30 minutes before reweight the crucible within the samples, the percentage of ash content was calculated using the following formula.

$$
\text { Total ash }(\%)=\frac{\text { Weight of ash }}{\text { Weight of sample }} \times 100
$$

Crude Fat: The crude fat content was determined through soxhlet extraction method described in AOAC (2000) [23]. $5 \mathrm{~g}$ of dry papaya powder was weighted into a previously prepared extraction thimble. The mouth of the thimble was plugged with fat free absorbent cotton wool. The receiver flask of the soxhlet was clean, dried and weighted accurately before the thimble with sample was introduced into the soxhlet extractor. The apparatus was assembled and filled 
with petroleum spirit to half capacity of the volume of the flask before the fat of the sample was extracted for 4 hours. The amount of crude fat was calculated as the following formula:

$$
\text { Crude fat }(\%)=(\mathrm{WF}-\mathrm{W}) / \mathrm{S} \times 100
$$

Where, WF=weight of the receiver flask and fat deposits $\mathrm{W}=$ weight of empty receiver flask only.

$\mathrm{S}=$ Weight of sample used.

Determination of crude fiber content: The crude fiber content determination was performed according to the standard method AOAC (2000) [24]. 2 grams of dry papaya sample was defatted using soxilet extractor. The fat free sample was transferred into a one-liter (1 liter) beaker. Boiling water was added with $25 \mathrm{ml}$ of $2.5 \mathrm{M} \mathrm{H}_{2} \mathrm{SO}_{4}$ was mixed and the volume was made up to $200 \mathrm{ml}$ level. Then, the mixture was boiled for $30 \mathrm{~min}$ and filtered by means of suction filtration through the butcher filter. The residue was washed twice with boiling water and transferred into the beaker. Then, $25 \mathrm{ml}$ of $2.5 \mathrm{M} \mathrm{NaOH}$ was added to it and diluted to the $200 \mathrm{ml}$ mark. The beaker was heat and boils for $30 \mathrm{~min}$ and another filtering procedure were done. The resulting residue was quantitatively transferred to a porcelain crucible. Finally, the fiber cake was extracted and dried by moisturizing with small portion of ethanol. The extracted fiber cake was dried with crucible at $100^{\circ} \mathrm{C}$ to a constant weight, cool and weighed (W1) and then the dried content of the crucible was incinerated at $600^{\circ} \mathrm{C}$ for $3 \mathrm{hrs}$ in a muffle furnace until all the carbonaceous matter was burnt. The crucible was cold in the desiccator and weighted (W2). The crude fat was calculated as follow:

$$
\text { Crude fiber }(\%)=((\mathrm{W} 1-\mathrm{W} 2) / \mathrm{W})) \times 100
$$

Where, W1=weight in gram of porcelain crucible and content before ashing

$\mathrm{W} 2=$ weight in gram of porcelain crucible containing ash

$\mathrm{W}=$ weight of sample in gram

Crude protein content: The crude protein content would be determined according to (AOAC, 2000) using the official by the Kjeldhal method $[25,26]$. Fresh samples of $0.5 \mathrm{~g}$ would be taken in a test tube and $6 \mathrm{ml}$ of concentrated sulfuric acid would be added and mixed, and $3.5 \mathrm{~mL}$ of $30 \%$ hydrogen peroxide would be added step by step. Three gram of catalyst mixture (powdered $0.5 \mathrm{~g}$ of selenium metal with $100 \mathrm{~g}$ of potassium sulfate) would be added into each tube, and allowed to stand for about 10 minutes. The violet reaction had terminated, the tubes would be shaken and placed back to the rack. After the temperature of the digester reached $370^{\circ} \mathrm{C}$, the tubes should be lowered into the digester. The digestion would be allowed to continue until a clear solution would be obtained, about 4 hours. The tubes in the rack would be cooled in a fume hood; $25 \mathrm{~mL}$ of de-ionized water would be added, and shaken to avoid precipitation of sulfate in the solution. A $250 \mathrm{~mL}$ conical flask containing $25 \mathrm{~mL}$ of boric acid, $25 \mathrm{~mL}$ of de-ionized water and an indicator solution would be placed under the condenser of the distiller with its tips immersed into the solution. The above digested solution would be transferred into the sample compartment of the distiller. Sodium hydroxide solution $(40 \%)$ would be added $(40 \mathrm{~mL})$ into the digested and diluted solution. The distillation process would be continued for some minute until a total volume reached between $250 \mathrm{ml}$. The tip of the distiller would be rinsed with a few milliliters of water before the receiver would remove. Finally, the distillate solution would be titrated using $0.1 \mathrm{~N}$ hydrochloric acid until reddish color appeared. The crude protein would be determined using the formula below:

$$
\% \mathrm{~N}=\frac{(\mathrm{V} \mathrm{HCl} \text { sample}-\mathrm{V} \mathrm{HCl} \text { blank }) \times \mathrm{N} \mathrm{HCl} \times 14.0}{\text { Weight of sample }(\mathrm{Wt} .)} \times 100
$$

$\%$ Protein $=\% \mathrm{~N}$ X 6.25

Where:

$\% \mathrm{~N}=$ percent of nitrogen

$\mathrm{N}=$ is the normality of $\mathrm{HCL}(0.1 \mathrm{~N})$,

$\mathrm{Wt}$.=weight of sample in gram.

$14.0=$ molecular weight of nitrogen

$\mathrm{V} \mathrm{HCl}=$ volume consumed by the sample in liter to the end point of titration,

$\mathrm{V} \mathrm{HCl}$ blank=Volume consumed by the blank (without sample)

Total Carotenoid Determination: The total carotenoid content of the sample was performed through harvest plus crops methods of spectrophotometrically using the method described by [27]. About $5 \mathrm{~g}$ of papaya flesh sample and $3 \mathrm{~g}$ of Hyflosupercel (Celite) were weighted and transferred into a mortar, and then the mixture was grounded with pestle by adding with $50 \mathrm{~mL}$ of cold acetone (acetone left in the refrigerator for about 2 ha). It was then filtered with suction filtration through Buchner funnel with filter paper. Then the extract (liquid) sample was put in to a $500-\mathrm{mL}$ separator funnel and $40 \mathrm{~mL}$ of petroleum ether was added and mixed with the extract in the separator funnel. $300 \mathrm{~mL}$ of distilled water was added slowly and allowed to flow along the walls of the funnel. The upper phase left in the funnels was washed 3-4 times with $200 \mathrm{~mL}$ distilled water. The petroleum ether phase was collected in a $50-\mathrm{mL}$ volumetric flask, making the solution pass through a small funnel containing about $15 \mathrm{~g}$ of anhydrous sodium sulfate to remove residual water. The sample was made up to volume of $50 \mathrm{ml}$ by adding petroleum ether and the absorbance was read at $450 \mathrm{~nm}$ using UV-spectrophotometer. The total carotenoid was calculated with the following formula.

$$
\text { Total carotenoid }(\mu \mathrm{g} / \mathrm{g})=\left[\mathrm{A} \times \text { volume }(\mathrm{mL}) \times 10^{4}\right] /\left[\mathrm{A}_{1 \mathrm{~cm}}{ }^{1 \%} \times \text { sample weight }(\mathrm{g})\right]
$$

Where $\mathrm{A}=$ absorbance; volume $=$ total volume of extract $=50$ $\mathrm{mL}$;

$\mathrm{A}^{1 \%}{ }_{1 \mathrm{~cm}}=$ absorption coefficient of $\beta$-carotene in petroleum ether (2592).

VitaminC (Ascorbic Acid): The vitamin c content was determined through the standard methods of Vitamin Assay 
[28].

\subsection{Sensory Analysis}

The sensory analysis was conducted by the semi-trained panelist of Melkassa agricultural research staff members accordingly the standard procedures. Statistical analysis of the data was carried out using analysis of variance (ANOVA) technique of completely randomized design (CRD) and all pair wise comparisons test whereas; the Tukey HSD was used for comparison of the treatment means at $\mathrm{P}<0.05$

\section{Results and Discussion}

\subsection{Physical Properties of Papaya Fruit}

The three papaya fruits varieties were subjected to statistical analysis in respect to their physical and chemical characteristics presented in Tables 1 and 2. The fruit weight of the different papaya varieties were varied from the range 355.72 to $1082.6 \mathrm{gm}$ (Table 1). The highest fruit weight was recorded in MK-121 and the lowest in CMF-078 variety. Among the varieties, the diameter of the fruit was recorded the maximum in MK-121 and the lowest in CMF-078. As regards to length, it was showed the maximum value in MK121. Most of the color of fruit was indicated the fruit ripeness even though some fruits skin colors is not (avocado). In case of MK-121 varieties of papaya, the skin and the flash color are the same. However, the rest of two varieties of papaya have been different skin and flash colors. The detailed data of the three papaya varieties were showed different in physical character such as length, weight, and diameter as showed below in the Table 1 .

Table 1. The statistical analysis of the physical data of papaya varieties.

\begin{tabular}{|c|c|c|c|c|c|c|}
\hline Varities & Length (mm) & Wedith (mm) & Weight (gm) & Diameter (mm) & Flesh Color & Skin Color \\
\hline KK-103 & $186.72^{\mathrm{b}}$ & $82.782^{\mathrm{b}}$ & $538.92^{\mathrm{b}}$ & $38.900^{\mathrm{b}}$ & Reddish orange & Yellowish green \\
\hline MK-121 & $250.07^{\mathrm{a}}$ & $105.38^{\mathrm{a}}$ & $1082.6^{\mathrm{a}}$ & $44.182^{\mathrm{a}}$ & Bright yellow & Bright yellow \\
\hline CMF-078 & $138.76^{\mathrm{c}}$ & $77.870^{\mathrm{b}}$ & $355.72^{c}$ & $29.957^{c}$ & Reddish orange & Yellow \\
\hline Mean & 191.85 & 88.678 & 659.08 & 37.680 & & \\
\hline $\mathrm{CV}$ & 4.03 & 6.610 & 9.750 & 4.530 & & \\
\hline LSD & 47.96 & 4.912 & 183.20 & 5.282 & & \\
\hline
\end{tabular}

Note: The table indicated which have the same superscript latter are not significant difference atp $>0.05$.

\subsection{Chemical Parameters of Papaya Fruit}

The statistical data on the chemical parameters was presented in Table 2. Based on this statistical data some of the parameters were observed that chemical composition content of selected papaya varieties were not showed much significantly difference $(\mathrm{p}<0.05)$ except the vitamin $\mathrm{C}$ content. The $\mathrm{pH}$ content of the three papaya fruits was not showed significantly different at $p<0.05$. The TSS (Total soluble solid) value of the three papaya fruit were varied from 10.287 to 12.620 brix. In this case, the TSS value of KK-103 was showed the higher value and CMF-078 Varity was showed the lowest TTS value compared with other selected papaya varieties. The TSS values of papaya in this study highly consistent with the study have been conducted by Zeman and Mekonen teams [29, 30]. Among the variety studied, the acidity (as citric acid) was ranged from 1.454 (MK-121) to $1.978 \mathrm{~g} / 1$ (CMF-078). The acidity value of the three papaya fruit of this study was consisted with the research work of have been coundacted with [6, 30]. Carotenoid is best interesting nutritional part of fruit which have a yellow flesh color like mango, papaya, etc., so in this study the two of papaya fruit varieties the total carotenoid contents were not significant at $p<0.05$. However, from the three papaya fruit a variety the MK-121 $(18.912 \mu \mathrm{g} / \mathrm{g})$ has showed high value of total carotenoid compared with other the two varieties. The Vitamin C (Ascorbic Acid) content of pulp was ranged from 30.854 to $43.407 \mathrm{mg} / 100 \mathrm{~g}$. The high value of ascorbic acid/vitamin $\mathrm{C}$ content was recorded inMK121 and the lowest content was recorded in CMF-078 varieties of papaya pulp.

Table 2. The statistical analysis of the chemical parameters data of papaya varieties.

\begin{tabular}{|c|c|c|c|c|c|}
\hline Varieties & PH & TSS (brix) & Citric acid (g/l) & Total carotenoid $(\mu \mathrm{g} / \mathrm{g})$ & vitamin C (mg/100g) \\
\hline kk-103 & $5.667^{\mathrm{a}}$ & $12.620^{\mathrm{a}}$ & $1.6043^{\mathrm{b}}$ & $13.847^{\mathrm{b}}$ & $36.507^{\mathrm{b}}$ \\
\hline MK-121 & $5.520^{\mathrm{a}}$ & $11.493^{\mathrm{ab}}$ & $1.4547^{\mathrm{b}}$ & $18.912^{\mathrm{a}}$ & $43.407^{\mathrm{a}}$ \\
\hline CMF-078 & $5.284^{\mathrm{a}}$ & $10.287^{\mathrm{b}}$ & $1.9787^{\mathrm{a}}$ & $13.699^{b}$ & $30.854^{\mathrm{c}}$ \\
\hline Mean & 5.49 & 11.47 & 1.68 & 15.49 & 36.922 \\
\hline $\mathrm{CV}$ & 3.78 & 5.89 & 8.03 & 8.80 & 4.21 \\
\hline LSD & 0.52 & 1.69 & 0.34 & 3.42 & 3.8924 \\
\hline
\end{tabular}

Note: The table indicated which have the same superscript latter are not significant difference at $\mathrm{p}>0.05$.

\subsection{Sensory Evaluation}

Most of the studies on fresh-cut fruits have been concerned with market quality determined objectively and subjectively by color, sensory and texture measurements [31]. In this study sensory evaluation of the three papaya varieties were performed and the analysis was done for the complete ripe papaya fruit. Sensory studies have been carried out to evaluate their quality perception such as color, flavor, sourness and sweetness of the fruit with semi-trained panelists and by using five hedonic scale methods.

Statistically, in case of color, flavor, sourness and 
sweetness MK-121 Varity was showed significance difference and a higher value than the other two of varieties of papaya whereas except sweetness; - the color, flavor and sourness of the two fruit such as CMF-078 and kk-103 have the same in statistics value. Accordingly the panelist result in over all acceptability of the sensory CMF-078 is better than the others and the result showed statistically different at $\mathrm{P}<0.05$.

Table 3. Sensorial data analysis of papaya varieties.

\begin{tabular}{|c|c|c|c|c|c|}
\hline Varieties & Color & Flavor & Sourness & Sweetness & Overall acceptability \\
\hline kk-103 & $3.4867^{b}$ & $3.229^{\mathrm{b}}$ & $3.0383^{\mathrm{b}}$ & $2.8897^{b}$ & $2.9997^{\mathrm{c}}$ \\
\hline MK-121 & $4.4133^{\mathrm{a}}$ & $4.594^{\mathrm{a}}$ & $4.1537^{\mathrm{a}}$ & $3.9980^{\mathrm{a}}$ & $3.9623^{\mathrm{b}}$ \\
\hline CMF-078 & $3.2300^{\mathrm{b}}$ & $3.3083^{b}$ & $3.4557^{\mathrm{b}}$ & $4.1280^{\mathrm{a}}$ & $4.7457^{\mathrm{a}}$ \\
\hline Mean & 3.71 & 3.71 & 3.55 & 3.67 & 3.90 \\
\hline $\mathrm{CV}$ & 5.92 & 3.25 & 4.99 & 4.02 & 2.83 \\
\hline LSD & 0.55 & 0.30 & 0.44 & 0.37 & 0.28 \\
\hline
\end{tabular}

1=Dislike Very Much, 2=Dislike, 3=Neither like nor dislike, 4=Like, 5=Like very much.

Note: The table indicated which have the same superscript latter are not significant difference at $\mathrm{p}>0.05$.

\subsection{Proximate Compositions of Papaya Fruit}

The proximate composition of papaya fruit statistical data are presented in Table 4. The data showed in Table 4, the moisture content of the three papaya varieties were significantly different at $\mathrm{p}<0.05$ while the range of moisture content was from 87.787 to $90.857 \%$. The KK-103 Varity was showed high value compared with the others varieties. The higher moisture content of the fruit was expected the more exposed to the deterioration/microbial growth. The ash content was ranged from 0.476 (CMF-078) to 0.552 (MK121). The statistical data showed the ash content was showed a significant difference among varieties. The protein, fat and fiber contents these parameters majorly are not a big deal in fruit and vegetable except some fruits. Because, mostly these parameters are available in high value in cereals, pulse and animal products. However, from this study those varieties of KK-103, CMF-078 were recorded a high value of protein, fat and fiber content respectively. In carbohydrate and energy value, those varieties of MK-121 were recorded in high value. Statistically there were a significant difference in both Carbohydrate and energy value of the varieties of the papaya fruit.

Table 4. The statistical analysis of the proximate compositions data of papaya varieties.

\begin{tabular}{|c|c|c|c|c|c|c|c|}
\hline Varieties & Moisture & Ash & Protein & Fat & Fiber & CHIO \% & Energy (kcal/g) \\
\hline KK-103 & $90.857^{\mathrm{a}}$ & $0.485^{\mathrm{b}}$ & $0.907^{\mathrm{a}}$ & $0.215^{\mathrm{b}}$ & $0.732^{\mathrm{c}}$ & $7.543^{c}$ & $32.744^{b}$ \\
\hline MK-121 & $87.787^{\mathrm{c}}$ & $0.552^{\mathrm{a}}$ & $0.866^{\mathrm{a}}$ & $0.238^{\mathrm{b}}$ & $0.888^{\mathrm{b}}$ & $10.556^{\mathrm{a}}$ & $44.280^{\mathrm{a}}$ \\
\hline CMF-078 & $89.704^{b}$ & $0.476^{\mathrm{b}}$ & $0.200^{\mathrm{b}}$ & $0.293^{\mathrm{a}}$ & $0.995^{\mathrm{a}}$ & $9.327^{\mathrm{b}}$ & $36.765^{b}$ \\
\hline Mean & 89.45 & 0.50 & 0.67 & 0.25 & 0.87 & 9.14 & 37.93 \\
\hline $\mathrm{CV}$ & 0.51 & 1.85 & 3.18 & 4.68 & 2.89 & 4.97 & 4.92 \\
\hline LSD & 1.14 & 0.023 & 0.05 & 0.03 & 0.06 & 1.14 & 4.68 \\
\hline
\end{tabular}

Note: The table indicated which have the same superscript latter are not significant difference at $\mathrm{p}>0.05$.

\section{Conclusion and Recommendation}

Accordingly, this study it is evident that the physicochemical parameters of papaya Varieties differed from one other, which is supposed to be due to different genetic makeup. In addition to this the varieties are because of the difference in their total fruit development. The differences in physico-chemical composition of different papaya varieties are in agreement with the findings of others workers. However, the present study indicates that the fruit of CMF078 is best since the overall acceptable value for the customer is good. In addition, the variety of MK-121 had a good carbohydrate and energy value than the others and it is good as a source of carbohydrate and energy. Not only had that it had also a better vitamin $\mathrm{C}$ and total carotenoid content. So, in this research work the researcher recommended to for fresh consumption of papaya fruit, variety MK-121 is the best in different aspects and it will also use for processing purpose.

\section{Conflict of Interest}

The authors have no conflict of interest.

\section{Acknowledgements}

Financial support received from the department of food science and nutrition research directorate, EIAR is gratefully acknowledged. The authors are grateful to Melkassa Agricultural research center, food science and horticulture researchers for their help.

\section{References}

[1] Khatun, H., et al., Effect of papaya and storage time on the quality of the newly developed papaya crackers. Journal of Experimental Biology, 2016. 4: p. 2. 
[2] Ming, R., et al., The draft genome of the transgenic tropical fruit tree papaya (Carica papaya Linnaeus). Nature, 2008. 452 (7190): p. 991.

[3] Subenthiran, S., et al., Carica papaya leaves juice significantly accelerates the rate of increase in platelet count among patients with dengue fever and dengue haemorrhagic fever. Evidence-Based Complementary and Alternative Medicine, 2013. 2013

[4] Begum, M., Phytochemical and pharmacological investigation of Carica papaya leaf. 2014, East west University.

[5] Rahmatullah, M., et al., Medicinal plants used for treatment of diabetes by the Marakh sect of the Garo tribe living in Mymensingh district, Bangladesh. African Journal of Traditional, Complementary and Alternative Medicines, 2012. 9 (3): p. 380-385.

[6] Zuhair, R., et al., Antioxidant activity and physicochemical properties changes of papaya (Carica papaya L. cv. Hongkong) during different ripening stage. International Food Research Journal, 2013. 20 (4): p. 1653.

[7] Van Wyk, B.-E. and M. Wink, Medicinal plants of the world. 2018: CABI.

[8] Cavalcante, Í. H. L., et al., Physical and chemical characteristics of tropical and non-conventional fruits, in Food industrial processes-methods and equipment. 2012, Intech Open.

[9] de Sousa Miranda, J. M. and A. B. G. Martins, Physical and Chemical Characteristics of Tropical and Non-Conventional Fruits. Food Industrial Processes: Methods and Equipment, 2012: p. 1.

[10] Bron, I. U. and A. P. Jacomino, Ripening and quality of 'Golden' papaya fruit harvested at different maturity stages. Brazilian Journal of Plant Physiology, 2006. 18 (3): p. 389-396.

[11] Barrett, D. M., J. C. Beaulieu, and R. Shewfelt, Color, flavor, texture, and nutritional quality of fresh-cut fruits and vegetables: desirable levels, instrumental and sensory measurement, and the effects of processing. Critical reviews in food science and nutrition, 2010. 50 (5): p. 369-389.

[12] Jadhav, S., S. B. Swami, and K. Pujari, Study the PhysicoChemical Properties of Sapota (Achras Sapota L.).

[13] Cavalcante, Í. H. L. and A. B. G. Martins, Physical and chemical characterization of dovyalis fruits. International journal of fruit science, 2005. 5 (4): p. 39-46.

[14] Schweiggert, R. M., et al., Influence of chromoplast morphology on carotenoid bioaccessibility of carrot, mango, papaya, and tomato. Food Chemistry, 2012. 135 (4): p. 2736-2742.

[15] Barberena, O. A. M., Effect of soil applied potassium silicate on papaya (Carica papaya L.) Plant growth, development, yields, physiology and, postharvest fruit quality. 2014: University of Florida.

[16] Ruiz, D., et al., Carotenoids from new apricot (Prunus armeniaca L.) varieties and their relationship with flesh and skin color. Journal of Agricultural and Food Chemistry, 2005. 53 (16): p. 6368-6374.
[17] Hawlader, M., et al., Drying of guava and papaya: Impact of different drying methods. Drying Technology, 2006. 24 (1): p. 77-87.

[18] Moreda, G., et al., Non-destructive technologies for fruit and vegetable size determination-a review. Journal of Food Engineering, 2009. 92 (2): p. 119-136.

[19] Iroka, C. F., et al., Effects of induced ripening on the proximate, biochemical and mineral compositions of Carica papaya (Pawpaw Fruit). European Journal of Medicinal Plants, 2016: p. 1-10.

[20] Bartolomé, A. P., P. Rupérez, and C. Fúster, Pineapple fruit: morphological characteristics, chemical composition and sensory analysis of Red Spanish and Smooth Cayenne cultivars. Food Chemistry, 1995. 53 (1): p. 75-79.

[21] Visessanguan, W., et al., Influence of minced pork and rind ratios on physico-chemical and sensory quality of Nham-a Thai fermented pork sausage. Meat science, 2005. 69 (2): p. 355-362.

[22] Sluiter, A., et al., Determination of ash in biomass. National Renewable Energy Laboratory, 2008 (NREL/TP-510-42622).

[23] Rubio-Rodríguez, N., et al., Supercritical fluid extraction of fish oil from fish by-products: A comparison with other extraction methods. Journal of Food Engineering, 2012. 109 (2): p. 238-248.

[24] Benjama, O. and P. Masniyom, Nutritional composition and physicochemical properties of two green seaweeds (Ulva pertusa and U. intestinalis) from the Pattani Bay in Southern Thailand. Sonklanakarin Journal of Science and Technology, 2011. 33 (5): p. 575.

[25] Chemists, A. o. O. A., Protein in grains. Method 979.09. Official Method of Analysis of AOAC International, 2000: p. 30-34.

[26] Beljkaš, B., et al., Rapid method for determination of protein content in cereals and oilseeds: validation, measurement uncertainty and comparison with the Kjeldahl method. Accreditation and quality assurance, 2010. 15 (10): p. 555-561.

[27] Chavez, A., et al., Retention of carotenoids in cassava roots submitted to different processing methods. Journal of the Science of Food and Agriculture, 2007. 87 (3): p. 388-393.

[28] Hübner, U., et al., Effect of 1 year $\mathrm{B}$ and $\mathrm{D}$ vitamin supplementation on LINE-1 repetitive element methylation in older subjects. Clinical chemistry and laboratory medicine, 2013. 51 (3): p. 649-655.

[29] Zaman, W., et al., Physico-chemical composition of four papaya varieties grown at Rajshahi. Journal of Bio-science, 2006. 14: p. 83-86.

[30] Aguayo, E., V. Escalona, and F. Artés, Effect of cyclic exposure to ozone gas on physicochemical, sensorial and microbial quality of whole and sliced tomatoes. Postharvest Biology and Technology, 2006. 39 (2): p. 169-177.

[31] Ahvenainen, R., New approaches in improving the shelf life of minimally processed fruit and vegetables. Trends in Food Science \& Technology, 1996.7 (6): p. 179-187. 